Proc. Indian Acad. Sci. (Chem. Sci.), Vol. 112, No. 2, April 2000, pp. 147-151

(C) Indian Academy of Sciences

\title{
Replacing the hydrogen in the intermolecular hydrogen bond of the cyanuric acid-bipyridyl adduct by $\mathrm{Ag}(\mathrm{I})$
}

\author{
K SIVASHANKAR, ANUPAMA RANGANATHAN and \\ V R PEDIREDDI ${ }^{1, *}$ \\ Chemistry and Physics of Materials Unit, Jawaharlal Nehru Centre for \\ Advanced Scientific Research, Jakkur PO, Bangalore 560 064, India \\ ${ }^{1}$ Present address: Division of Organic Chemistry, National Chemical \\ Laboratory, Pune 411 008, India \\ e-mail: pediredi@ems.ncl.res.in
}

MS received 21 March 2000

\begin{abstract}
A complex between cyanuric acid (CA), 4,4'-bipyridyl (BP) and $\mathrm{Ag}(\mathrm{I})$, with the composition, $\left[\mathrm{Ag}_{2}\left(\mathrm{C}_{3} \mathrm{H}_{2} \mathrm{~N}_{3} \mathrm{O}_{3}-\kappa \mathrm{N}\right)_{2} \quad\left(\mathrm{C}_{10} \mathrm{H}_{8} \mathrm{~N}_{2}-\kappa \mathrm{N}\right)\right]$ has been prepared. Crystal structure analysis shows that it has a chain structure in which the $\mathrm{CA}$ molecules are linked to the $\mathrm{BP}$ units through silver atoms by the formation of $\mathrm{N}-\mathrm{Ag}-$ $\mathrm{N}$ bonds, wherein one of the hydrogens of $\mathrm{CA}$ is replaced by $\mathrm{Ag}(\mathrm{I})$, showing thereby the chains connected to one another by $\mathrm{N}-\mathrm{H}$...O hydrogen bonds formed between the CA molecules. This intermolecular chain structure resembles the chain structure of the CA.BP adduct where CA-BP-CA chains formed by $\mathrm{N}-\mathrm{H}$... $\mathrm{N}$ hydrogen bonds are linked to one another by $\mathrm{N}-\mathrm{H}$... O hydrogen bonds between the CA molecules.
\end{abstract}

Keywords. Cyanuric acid-Ag-4,4'-bipyridyl adduct; $\mathrm{N}-\mathrm{Ag}-\mathrm{N}$ chains; crystal structure analysis.

\section{Introduction}

Cyanuric acid (CA) forms interesting hydrogen-bonded structures with the aid of the three secondary cis-amide bonds ${ }^{1}$. It is known to form a variety of adducts when co-crystallized with heterocyclics and also with metal ions ${ }^{2}$. When co-crystallized with $4,4^{\prime}$-bipyridyl (BP), it forms different hydrogen-bonded assemblies depending on the solvent of crystallization, the structures bearing some resemblance to the hydrogen-bonded supramolecular assemblies of CA crystallized from the respective solvents ${ }^{3}$. CA also forms an adduct of the composition, $\mathrm{Ag}$.CA with $\mathrm{Ag}(\mathrm{I})$ which has a layer structure comprising two-dimensional sheets of silver atoms which are pillared by chains of CA molecules ${ }^{4}$. In this complex, two of the hydrogens of CA are replaced by Ag. Recently, a mercury complex of CA of the composition, $\mathrm{Hg}_{3}[\mathrm{CA}-\kappa \mathrm{N}]_{2} 3 \cdot 5 \mathrm{H}_{2} \mathrm{O}$ wherein $\mathrm{Hg}$ replaces all the hydrogens of CA has been prepared.

Co-crystallization of CA and BP from water gives a 1:1 adduct. This adduct has a

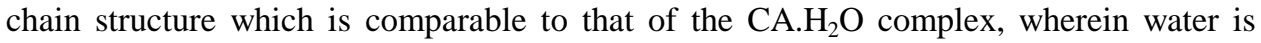
replaced by $\mathrm{BP}$ molecules to form $\mathrm{N}-\mathrm{H}$... $\mathrm{N}$ hydrogen bonds. The hydrogen-bonded chains of $\mathrm{CA}$ and $\mathrm{BP}$ are held together by $\mathrm{N}-\mathrm{H}$... O hydrogen bonds between the $\mathrm{CA}$

*For correspondence 
Table 1. Crystallographic data of the complex, $\left[\mathrm{Ag}_{2}\left(\mathrm{C}_{3} \mathrm{H}_{2} \mathrm{~N}_{3} \mathrm{O}_{3}-\kappa \mathrm{N}\right)_{2}\left(\mathrm{C}_{10} \mathrm{H}_{8} \mathrm{~N}_{2}-\kappa \mathrm{N}\right)\right]$.

\begin{tabular}{llll}
\hline Formula $\left[\mathrm{Ag}_{2}\left(\mathrm{C}_{3} \mathrm{H}_{2} \mathrm{~N}_{3} \mathrm{O}_{3}-\kappa \mathrm{N}\right)_{2}\left(\mathrm{C}_{10} \mathrm{H}_{8} \mathrm{~N}_{2}-\kappa \mathrm{N}\right)\right]$ & $\mu\left(\mathrm{mm}^{-1}\right)$ & $2 \cdot 168$ \\
Mol. wt. & $314 \cdot 04$ & Crystal size $(\mathrm{mm})$ & $0 \cdot 40 \times 0 \cdot 30 \times 0 \cdot 20$ \\
Crystal system & monoclinic & Diffractometer & Siemens, Smart CCD \\
Space group & $P 2_{1} / n$ & $\mathrm{~T}(\mathrm{~K})$ & $293(2)$ \\
$a(\AA)$ & $13 \cdot 089(2)$ & X-radiation & Mo- $K_{\alpha}$ \\
$b(\AA)$ & $4 \cdot 586(1)$ & $\theta$ range $(\mathrm{deg})$ & $1-24$ \\
$c(\AA)$ & $15 \cdot 996(2)$ & $h$ & -10 to 14 \\
$\alpha^{\circ}$ & 90 & $k$ & -5 to 5 \\
$\beta^{\circ}$ & $104 \cdot 75(1)$ & $l$ & -17 to 17 \\
$\gamma^{\circ}$ & 90 & Total reflections & 3640 \\
Cell volume $\left(\AA^{3}\right)$ & $928 \cdot 5(3)$ & Non-zero reflections & 1335 \\
$Z$ & 4 & $\sigma$-level & 3 \\
$\mathrm{~F}(000)$ & 612 & $R$ & $0 \cdot 0506$ \\
$d_{\text {calcd }}\left(\mathrm{g} . \mathrm{cm}^{-3}\right)$ & $2 \cdot 246$ & $R_{\mathrm{w}}$ & $0 \cdot 1105$ \\
$\lambda(\AA)$ & $0 \cdot 71073$ & max. $e\left(\AA^{-3}\right)$ & $1 \cdot 162$ \\
\hline & & &
\end{tabular}

Table 2. Atomic coordinates and equivalent isotropic displacement parameters $\left(\AA^{2}\right)$ of the complex, $\left[\mathrm{Ag}_{2}\left(\mathrm{C}_{3} \mathrm{H}_{2} \mathrm{~N}_{3} \mathrm{O}_{3}-\kappa \mathrm{N}\right)_{2}\left(\mathrm{C}_{10} \mathrm{H}_{8} \mathrm{~N}_{2}-\kappa \mathrm{N}\right)\right]$. $U_{(\mathrm{eq})}$ is defined as one-third of the trace of the orthogonalized $U_{i j}$ tensor.

\begin{tabular}{|c|c|c|c|c|}
\hline Atom & $x$ & $y$ & $z$ & $U_{(\mathrm{eq})}$ \\
\hline $\operatorname{Ag}(\mathrm{I})$ & $0 \cdot 6404(1)$ & $0 \cdot 2286(2)$ & $0 \cdot 8551(1)$ & $0 \cdot 036(1)$ \\
\hline N (3) & $0 \cdot 6671(6)$ & $0.0460(2)$ & $0 \cdot 9803(4)$ & $0.025(2)$ \\
\hline $\mathrm{O}(3)$ & $0 \cdot 5473(5)$ & -0.3005 (1) & $0.9221(4)$ & $0.032(2)$ \\
\hline $\mathrm{O}(1)$ & $0 \cdot 7895(5)$ & $0 \cdot 3815(1)$ & $1.0463(4)$ & $0.036(2)$ \\
\hline N (4) & $0 \cdot 6019(6)$ & $0 \cdot 3713(2)$ & $0 \cdot 7248(4)$ & $0.032(2)$ \\
\hline $\mathrm{O}(2)$ & $0 \cdot 6431(5)$ & $-0 \cdot 2005(1)$ & $1 \cdot 2135(4)$ & $0 \cdot 044(2)$ \\
\hline C (1) & $0.7300(7)$ & $0 \cdot 1831(2)$ & $1.0505(5)$ & $0.026(2)$ \\
\hline C (3) & $0 \cdot 6019(6)$ & $-0.1732(2)$ & $0.9863(5)$ & $0 \cdot 021(2)$ \\
\hline$C(2)$ & $0 \cdot 6527(7)$ & $-0 \cdot 1278$ & $1 \cdot 1428(5)$ & $0.026(2)$ \\
\hline $\mathrm{N}(2)$ & 0.5967 (7) & $-0.2577(2)$ & $1.0682(4)$ & $0.025(2)$ \\
\hline N (1) & $0 \cdot 7217(6)$ & $0.0825(2)$ & $1 \cdot 1308(4)$ & $0.026(2)$ \\
\hline C (6) & $0.5229(7)$ & $0.4745(2)$ & $0 \cdot 5470(5)$ & $0.026(2)$ \\
\hline$C(7)$ & $0.4803(8)$ & $0 \cdot 6161(2)$ & $0 \cdot 6082(5)$ & $0.031(2)$ \\
\hline$C(5)$ & $0 \cdot 6061(8)$ & $0 \cdot 2888(2)$ & $0 \cdot 5777(5)$ & $0.034(2)$ \\
\hline C (4) & $0.5228(9)$ & $0 \cdot 5521(3)$ & $0.6956(6)$ & $0.037(3)$ \\
\hline $\mathrm{H}(7)$ & $0.430(8)$ & $0.768(2)$ & $0.588(6)$ & $0.030(3)$ \\
\hline H (8) & $0.497(6)$ & $0.654(2)$ & $0.727(5)$ & $0.020(2)$ \\
\hline H (1) & $0.757(7)$ & $0 \cdot 184(2)$ & $1 \cdot 180(6)$ & $0 \cdot 040(3)$ \\
\hline $\mathrm{H}(5)$ & $0.630(7)$ & $0 \cdot 175(2)$ & $0.533(6)$ & $0.050(3)$ \\
\hline $\mathrm{H}(4)$ & $0.693(6)$ & $0 \cdot 107(2)$ & $0.676(5)$ & $0.023(3)$ \\
\hline $\mathrm{H}(2)$ & $0.569(7)$ & $-0 \cdot 380(2)$ & $1.073(6)$ & $0.030(3)$ \\
\hline
\end{tabular}

molecules $^{3}$. We wanted to investigate whether the hydrogen in the intermolecular $\mathrm{N}-\mathrm{H}$... $\mathrm{N}$ bonds in CA.BP can be replaced by $\mathrm{Ag}(\mathrm{I})$ and hence this structure. For this purpose, we have synthesized a $\mathrm{Ag}(\mathrm{I})$ complex containing $\mathrm{CA}$ and $\mathrm{BP}$ by the hydrothermal method and studied its structure by crystallography. 


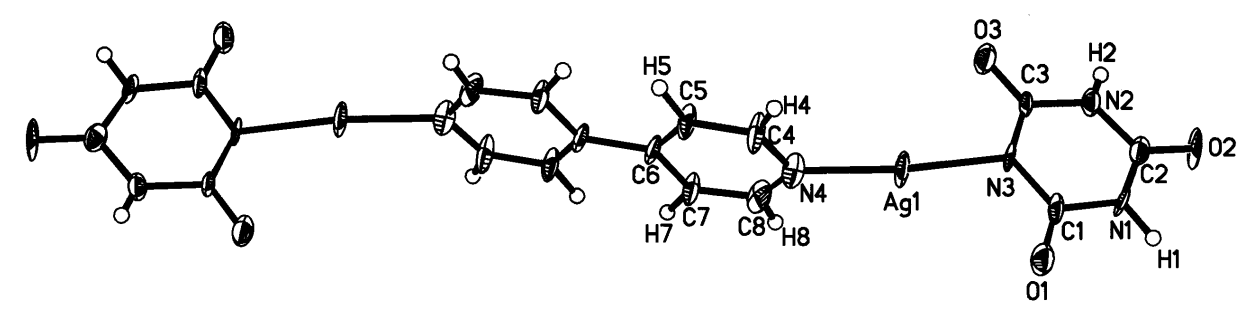

Figure 1. The asymmetric unit of $\mathbf{1 .}$

Table 3. Bond lengths $[\AA]$ and angles $\left[{ }^{\circ}\right]$ in $\left[\mathrm{Ag}_{2}\left(\mathrm{C}_{3} \mathrm{H}_{2} \mathrm{~N}_{3} \mathrm{O}_{3}-\kappa \mathrm{N}\right)_{2}\left(\mathrm{C}_{10} \mathrm{H}_{8} \mathrm{~N}_{2}-\kappa \mathrm{N}\right)\right]$.

\begin{tabular}{|c|c|c|c|}
\hline $\operatorname{Ag}(1)-\mathrm{N}(3)$ & $2 \cdot 116(6)$ & $\mathrm{Ag}(1)-\mathrm{N}(4)$ & $2 \cdot 120(7)$ \\
\hline $\mathrm{N}(3)-\mathrm{C}(3)$ & $1.338(10)$ & $\mathrm{N}(3)-\mathrm{C}(1)$ & 1.365 (11) \\
\hline $\mathrm{O}(3)-\mathrm{C}(3)$ & $1.238(10)$ & $\mathrm{O}(1)-\mathrm{C}(1)$ & $1.210(10)$ \\
\hline N (4)-C (8) & $1.316(12)$ & $\mathrm{N}(4)-\mathrm{C}(4)$ & $1.349(12)$ \\
\hline $\mathrm{O}(2)-\mathrm{C}(2)$ & $1.215(10)$ & $\mathrm{C}(1)-\mathrm{N}(1)$ & $1.395(10)$ \\
\hline $\mathrm{C}(3)-\mathrm{N}(2)$ & $1.384(11)$ & $\mathrm{C}(2)-\mathrm{N}(2)$ & $1.368(11)$ \\
\hline $\mathrm{C}(2)-\mathrm{N}(1)$ & $1.368(11)$ & $\mathrm{C}(6)-\mathrm{C}(5)$ & $1.372(12)$ \\
\hline $\mathrm{C}(6)-\mathrm{C}(7)$ & $1.404(12)$ & $\mathrm{C}(5)-\mathrm{C}(4)$ & $1.370(12)$ \\
\hline $\mathrm{C}(7)-\mathrm{C}(8)$ & $1.398(13)$ & & \\
\hline $\mathrm{N}(3)-\mathrm{Ag}(1)-\mathrm{N}(4)$ & $173 \cdot 5(3)$ & $\mathrm{C}(3)-\mathrm{N}(3)-\mathrm{C}(1)$ & $123 \cdot 3(7)$ \\
\hline $\mathrm{C}(3)-\mathrm{N}(3)-\mathrm{Ag}(1)$ & $114 \cdot 3(5)$ & $\mathrm{C}(1)-\mathrm{N}(3)-\mathrm{Ag}(1)$ & $121 \cdot 0(5)$ \\
\hline $\mathrm{C}(8)-\mathrm{N}(4)-\mathrm{C}(4)$ & $116 \cdot 3(8)$ & $\mathrm{C}(8)-\mathrm{N}(4)-\mathrm{Ag}(1)$ & $120 \cdot 8(6)$ \\
\hline $\mathrm{C}(4)-\mathrm{N}(4)-\mathrm{Ag}(1)$ & $121.8(7)$ & $\mathrm{O}(1)-\mathrm{C}(1)-\mathrm{N}(3)$ & $124 \cdot 3(7)$ \\
\hline $\mathrm{O}(1)-\mathrm{C}(1)-\mathrm{N}(1)$ & $120 \cdot 1(8)$ & $\mathrm{N}(3)-\mathrm{C}(2)-\mathrm{N}(1)$ & $115.6(8)$ \\
\hline $\mathrm{O}(3)-\mathrm{C}(3)-\mathrm{N}(3)$ & $122.6(7)$ & $\mathrm{O}(3)-\mathrm{C}(3)-\mathrm{N}(2)$ & $119 \cdot 7(8)$ \\
\hline $\mathrm{N}(3)-\mathrm{C}(3)-\mathrm{N}(2)$ & $117.7(8)$ & $\mathrm{O}(2)-\mathrm{C}(3)-\mathrm{N}(2)$ & $122 \cdot 2(9)$ \\
\hline $\mathrm{O}(2)-\mathrm{C}(2)-\mathrm{N}(1)$ & $123.5(8)$ & $\mathrm{N}(2)-\mathrm{C}(2)-\mathrm{N}(1)$ & $114.2(8)$ \\
\hline $\mathrm{C}(2)-\mathrm{N}(2)-\mathrm{C}(3)$ & $124.0(9)$ & $\mathrm{C}(2)-\mathrm{N}(1)-\mathrm{C}(1)$ & $124.9(8)$ \\
\hline $\mathrm{C}(5)-\mathrm{C}(6)-\mathrm{C}(7)$ & $117.2(8)$ & $\mathrm{C}(8)-\mathrm{C}(7)-\mathrm{C}(6)$ & $118 \cdot 3(9)$ \\
\hline $\mathrm{C}(4)-\mathrm{C}(5)-\mathrm{C}(6)$ & $120 \cdot 1(8)$ & $\mathrm{N}(4)-\mathrm{C}(4)-\mathrm{C}(5)$ & $123 \cdot 7(10)$ \\
\hline $\mathrm{N}(4)-\mathrm{C}(8)-\mathrm{C}(7)$ & $124.3(9)$ & & \\
\hline
\end{tabular}

The complex containing CA, BP and $\mathrm{Ag}(\mathrm{I})$, $\mathbf{1}$, with the composition, $\left[\mathrm{Ag}_{2}\left(\mathrm{C}_{3} \mathrm{H}_{2} \mathrm{~N}_{3} \mathrm{O}_{3^{-}}\right.\right.$ $\left.\kappa \mathrm{N}]_{2}\left(\mathrm{C}_{10} \mathrm{H}_{8} \mathrm{~N}_{2}-\kappa \mathrm{N}\right)\right]$ was prepared by the hydrothermal method as follows. In a typical preparation, $10 \mathrm{ml}$ of a solution of $\mathrm{CA}, \mathrm{BP}$ and $\mathrm{AgNO}_{3}$ (1:1:1 molar ratio) taken in a teflon flask was placed in a steel bomb and kept in an oven maintained at $160^{\circ} \mathrm{C}$ for $36 \mathrm{~h}$ and then cooled to room temperature over a period of $6 \mathrm{~h}$ to obtain good quality single crystals of the complex. The crystals were colourless and had a needle-shaped geometry. This complex crystallizes in a $\mathrm{P} 2{ }_{1} / \mathrm{n}$ space group. The intensity data of the single crystals of the complex, $\left[\mathrm{Ag}_{2}\left(\mathrm{C}_{3} \mathrm{H}_{2} \mathrm{~N}_{3} \mathrm{O}_{3}-\kappa \mathrm{N}\right)_{2}\left(\mathrm{C}_{10} \mathrm{H}_{8} \mathrm{~N}_{2}-\kappa \mathrm{N}\right)\right]$ were collected on a Siemens diffractometer equipped with a CCD area detector ${ }^{5}$ using Mo- $K_{\alpha}$ radiation in $\omega-2 \theta$ mode. Important crystal parameters related to data collection and the structures are given in table 1. The structure was determined and refined using the SHELXTL package ${ }^{6}$. The refinements were uncomplicated and all the non-hydrogen atoms were refined anisotropically. Hydrogen atoms obtained from Fourier maps were refined isotropically. The atomic coordinates are listed in table 2. Selected bond lengths and angles are given in table 3. The hydrogen-bond lengths and angles were computed using PLATON ${ }^{7}$ and the plots of arrangement of molecules were generated using XP package ${ }^{6}$. 


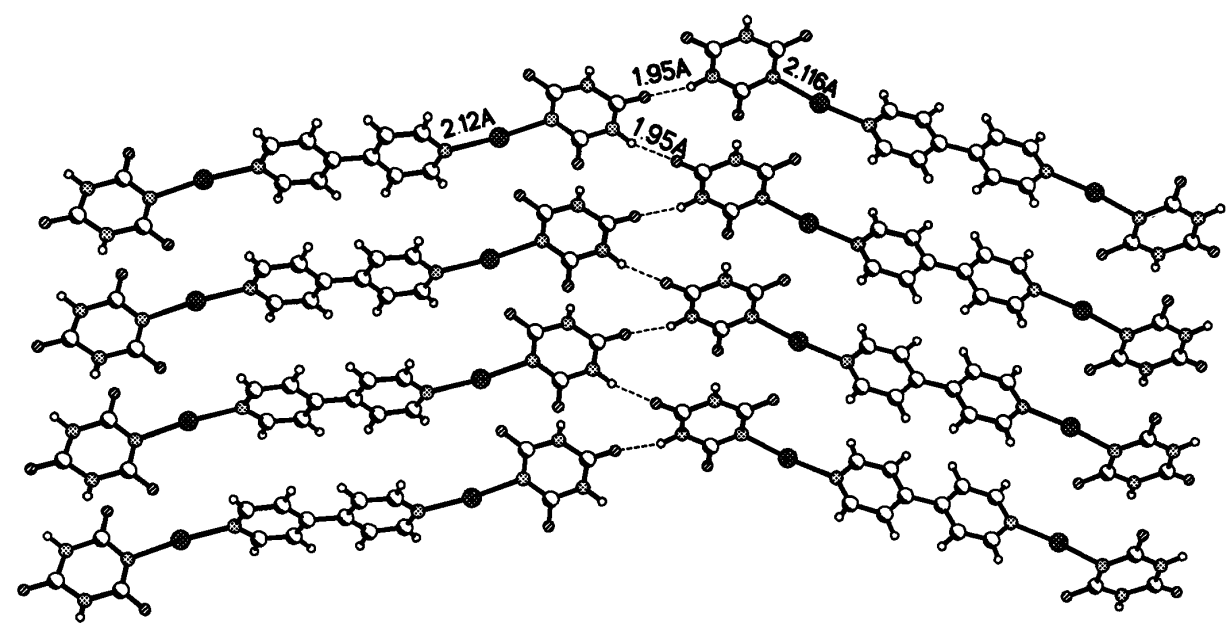

Figure 2. Two-dimensional structure of $\mathbf{1}$ showing the intermolecular CA-Ag-BP chains hydrogen-bonded to one another through CA molecules.

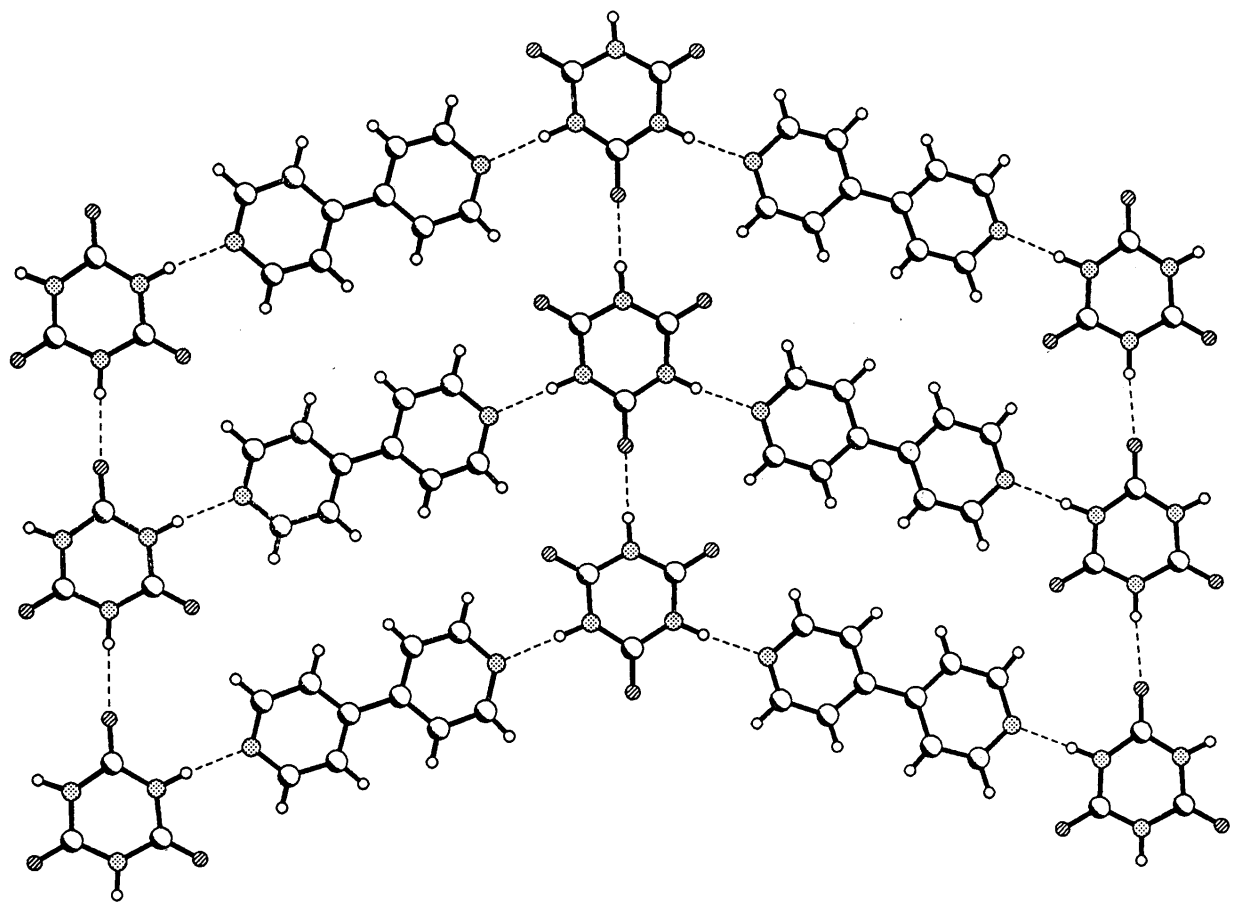

Figure 3. Structure of the CA.BP adduct showing hydrogen-bonded CA.BP chains, in turn hydrogen-bonded to one another through CA molecules.

We show the asymmetric unit of the complex 1 in figure 1 . The asymmetric unit contains two CA molecules, one BP molecule and two Ag atoms. We show the detailed 
structure of the complex in figure 2. The complex has a chain structure resembling the structure of the CA.BP adduct (figure 3). What is interesting is that $\mathrm{Ag}(\mathrm{I})$ replaces one of the hydrogens of $\mathrm{CA}$ to bond to the ring nitrogen of $\mathrm{BP}$ forming $\mathrm{N}-\mathrm{Ag}-\mathrm{N}$ bonds $(\mathrm{N}-\mathrm{Ag}$, $2.12 \AA)$. Thus, the $\operatorname{Ag}(\mathrm{I})$ ion acts like a proton in forming the intermolecular chain. The $\mathrm{CA}-\mathrm{Ag}-\mathrm{BP}-\mathrm{Ag}-\mathrm{CA}$ chains are connected to one another by intermolecular N-H...O bonds (H...O, $1.95 \AA$ ), between the CA molecules of adjacent chains.

The $\mathrm{N}-\mathrm{Ag}-\mathrm{N}$ angle in the complex is $173 \cdot 5^{\circ}$, unlike in the melamine- $\mathrm{AgNO}_{3}$ complex where it is $127^{\circ}$. The $\mathrm{Ag}-\mathrm{N}$ distance is $2 \cdot 12 \AA$. In comparison to the melamine- $4,4^{\prime}$ bipyridyl complex where the two pyridine rings of $\mathrm{BP}$ are not coplanar, the two pyridine rings in this complex, $\left[\mathrm{Ag}_{2}\left(\mathrm{C}_{3} \mathrm{H}_{2} \mathrm{~N}_{3} \mathrm{O}_{3}-\kappa \mathrm{N}\right)_{2}\left(\mathrm{C}_{10} \mathrm{H}_{8} \mathrm{~N}_{2}-\kappa \mathrm{N}\right)\right]$ are coplanar, the torsion angle being only $0.7^{\circ}$.

\section{Acknowledgement}

The authors thank Professor C N R Rao, FRS for suggesting the problem and helpful discussions.

\section{References}

1. Coppens P and Vos A 1971 Acta Crystallogr. B27 146; Chang-Zhang C, Jian-Qiu S, Zhou-Bin L, Dong-Shou G and Ding H X L 1995 J. Struct. Chem. 14241

2. Mathias J P, Seto C T, Simanek E E and Whitesides G M 1994 J. Am. Chem. Soc. 116 1725; Ranganathan A, Pedireddi V R and Rao C N R 1999 J. Am. Chem. Soc. 121 1752; Agre V M, Sisoeva T F, Trunor V K, Gurevich M Z and Branzburg M Z 1986 Koord. Khim. 12 122; Falvello L R, Pascual I and Tomas M 1995 Inorg. Chim. Acta 229 135; Falvello L R, Pascual I, Tomas M and Urriolabeitia E P 1995 J. Am. Chem. Soc. 11911894

3. Ranganathan A, Pedireddi V R and Rao C N R 2000 J. Mol. Struct. 52287

4. Rao C N R, Ranganathan A, Pedireddi V R and Raju A R 2000 Chem. Commun. 39

5. Siemens 1995 SMART System, Siemens Analytical X-ray Instrument Inc., Madison, Wisconsin, USA

6. Sheldrick G M 1993 SHELXTL, Users Manual, Siemens Analytical X-ray Instrument Inc., Madison, Wisconsin, USA

7. Spek A L 1995 PLATON, Molecular Geometry Program, University of Utrecht, The Netherlands 